\title{
Optimal Steroid Dosage with Three Successive Hydrodilatation Treatment for Adhesive Capsulitis of the Shoulder: A Randomized Controlled Study
}

\author{
Jong Moon Kim, MD ${ }^{1}$, Han Kyul Park, MD², Ji Seong Hong, MD³, Da Sol Ha, MD ${ }^{4}$, \\ Hyoung Seop Kim, MD', and Hyun Sun Lim, PhD $^{5}$
}

Background: Idiopathic adhesive capsulitis of the shoulder is a common disease, however, the optimal dosage of steroid in serial hydration has not been defined.

Objectives: The aim of this study is to find the optimal dosage of triamcinolone acetonide with serial hydrodilatation for adhesive capsulitis of the shoulder.

Study Design: Prospective, double blinded randomized controlled study. Setting: Secondary Training Hospital.

Methods: Forty-two patients with adhesive capsulitis of the shoulder were randomly assigned to $20 \mathrm{mg}$ or $40 \mathrm{mg}$ intraarticular steroid injection with hydrodilatation groups using a double blind method. Data were assessed by visual analog scale (VAS) for pain, range of motion (ROM) questionnaire, shoulder pain questionnaire, and actual shoulder ROM (flexion, abduction, inter- nal rotation, and external rotation). Data were collected before the injection and once every 4 weeks after the injection.

Results: The baseline characteristics of the patients were not statistically different. Both groups were compared with their pretreated status in all measurements. $(P<0.05)$. There were no statistical differences between groups between the measurements.

Limitations: The absence of a control group: a group that was administered hydrodilatation without steroid.

Conclusion: We suggest $20 \mathrm{mg}$ of steroid injection with serial hydrodilatation for adhesive capsulitis of the shoulder patients.

Key words: Injections, intra-articular, triamcinolone acetonide, lidocaine, shoulder pain, shoulder joint, pain management, bursitis, pain measurement, adhesive capsulitis
From : ${ }^{1}$ Department of Rehabilitation Medicine, CHA Bundang Medical Center; ${ }^{2}$ Departments and Research Institute of Rehabilitation Medicine, Yonsei University College of Medicine; ${ }^{3}$ Departments of Physical Medicine and Rehabilitation, Hando Hospital; ${ }^{4}$ Departments of Physical Medicine and Rehabilitation, National Health Insurance Corporation Ilsan Hospital; ${ }^{5}$ Department of Policy Research Affairs National Health Insurance Service Ilsan Hospital

Author for correspondence: Hyoung Seop Kim, MD

Address: Departments of Physical Medicine and Rehabilitation, National Health Insurance Ilsan Hospital, 100 Ilsan-roilsan-donggu, Goyang 10444

E-mail address: rehappydoc@gmail.com
Idiopathic adhesive capsulitis is a disease that first presents itself with pain around the shoulder for no discernible reason and leads to contraction of the affected joint. The disease affects $2-5 \%$ of the population, and is especially prevalent in 40-60 year old women $(1,2)$. Adhesive capsulitis was first described as frozen shoulder by Codman in 1934 (3) as a disease that is difficult to define, to treat, and to determine its etiology. In 1949, Neviasier (4) described the disease as adhesive capsulitis, but the etiology of the disease was not fully understood $(4,5)$. Some experts believe that adhesive capsulitis should be considered more as a syndrome rather than a disease, and that secondary adhesive capsulitis with clear precipitating 
factors should be considered a separate entity from the primary disease.

The disease is clinically diagnosed according to symptoms present, including capsular pattern disability, which is the inability to externally rotate the affected shoulder $(6,7)$. Radiographic imaging is used first to exclude other possible diagnoses, and to confirm that there are no radiographic anomalies, excluding osteoporosis.

Current treatment methods are conservative, and those that have been proven to be effective through various studies include procedures such as intraarticular steroid injection, hydrodilatation, suprascapular nerve block, physical therapy, and manipulation. However, there have not been studies comparing the efficacy among various methods or the efficacy of different combinations of treatment methods. There has also been a lack of studies on the optimum dosage for steroid injections with serial hydrodilatation (8-17). This study aims to determine the efficacy of the combination therapy of steroid injection with hydrodilatation, and to provide a guideline on optimum dosage of steroid for this method of treatment.

\section{METHODS}

\section{Patients}

From March 2013 through December 2015 patients with shoulder pain were recruited to the study. The study was approved by the institutional review board, and all patients enrolled gave written, informed consent in accordance with the principles set forth in the Declaration of Helsinki. A board-certified physiatrist with 7 years of musculoskeletal ultrasonographic experience (K.H.S) performed the physical examination, simple shoulder $\mathrm{x}$-ray, and ultrasonographic study to diagnose adhesive capsulitis. Adhesive capsulitis was diagnosed when internal rotation and external rotation was relatively more limited than flexion and abduction. Musculoskeletal ultrasonography was performed at 5-12 MHz with a Voluson i (GE Healthcare, Chicago, IL) linear array transducer.

Exclusion criteria were: full thickness tear of the supraspinatus tendon or total rupture in ultrasonographic study; presence of other shoulder pain such as subdeltoid bursitis, calcific tendinopathy, and supraspinatus tendinopathy (more than $2 \mathrm{~mm}$ difference compared to sound side in short axis view); previous trauma or operation history at the shoulder; previous steroid injection history at the shoulder by another hospital; bilateral adhesive capsulitis; patients with diabetes controlled by insulin injection; and loss to follow-up. Among 101 recruited patients, 42 patients fulfilled the inclusion criteria (Fig. 1). With a calculated effect size of 1.23 and an $\alpha$ of 0.05 , a power of 0.96 was achieved with 20 patients in each group (18).

\section{Randomization}

Forty-two patients with adhesive capsulitis were randomly assigned to $20 \mathrm{mg}$ or $40 \mathrm{mg}$ intraarticular steroid injection with hydrodilatation groups using a double-blind method. The $40 \mathrm{mg}$ group received a single injection of $1 \mathrm{~mL}$ of $40 \mathrm{mg}$ of steroid and $9 \mathrm{~mL}$ of $1 \%$ lidocaine, compared to the $20 \mathrm{mg}$ group which received $0.5 \mathrm{~mL}$ of $40 \mathrm{mg}$ of steroid and $9.5 \mathrm{~mL}$ of $1 \%$ lidocaine. After the first injection, 2 more injections consisting of $10 \mathrm{~mL}$ of $1 \%$ lidocaine for hydrodilatation were scheduled with a one week interval for both groups (Fig. 2).

\section{Interventions}

The injection was administered using a sterile technique with a disposable $10 \mathrm{~mL}$ syringe. Patients were requested to extend and internally rotate their shoulder in a sitting position. A23G, $6 \mathrm{~cm}$ long needle was inserted at the posterior side of the shoulder until the needle tip reached the intraarticular space in parallel to the transducer in longitudinal view by ultrasound guidance (Figs. 3,4). Each group was taught to perform exercises that stretch the shoulder joint during the treatment period (Figs. 5,6). For pain medication, an NSAID (meloxicam) was used twice a day.

\section{Evaluations and Assessment of Outcomes}

The degree of pain was measured using the visual analog scale (VAS). The VAS score was measured in relation to the degree of pain that patients experienced during their usual daily activities. The main outcome measures were VAS, range of motion (ROM) questionnaire, shoulder pain questionnaire, and ROM (flexion, abduction, internal rotation and external rotation). ROM was measured by using a goniometer. To compare the effects between each group, evaluations were carried out before injection, 


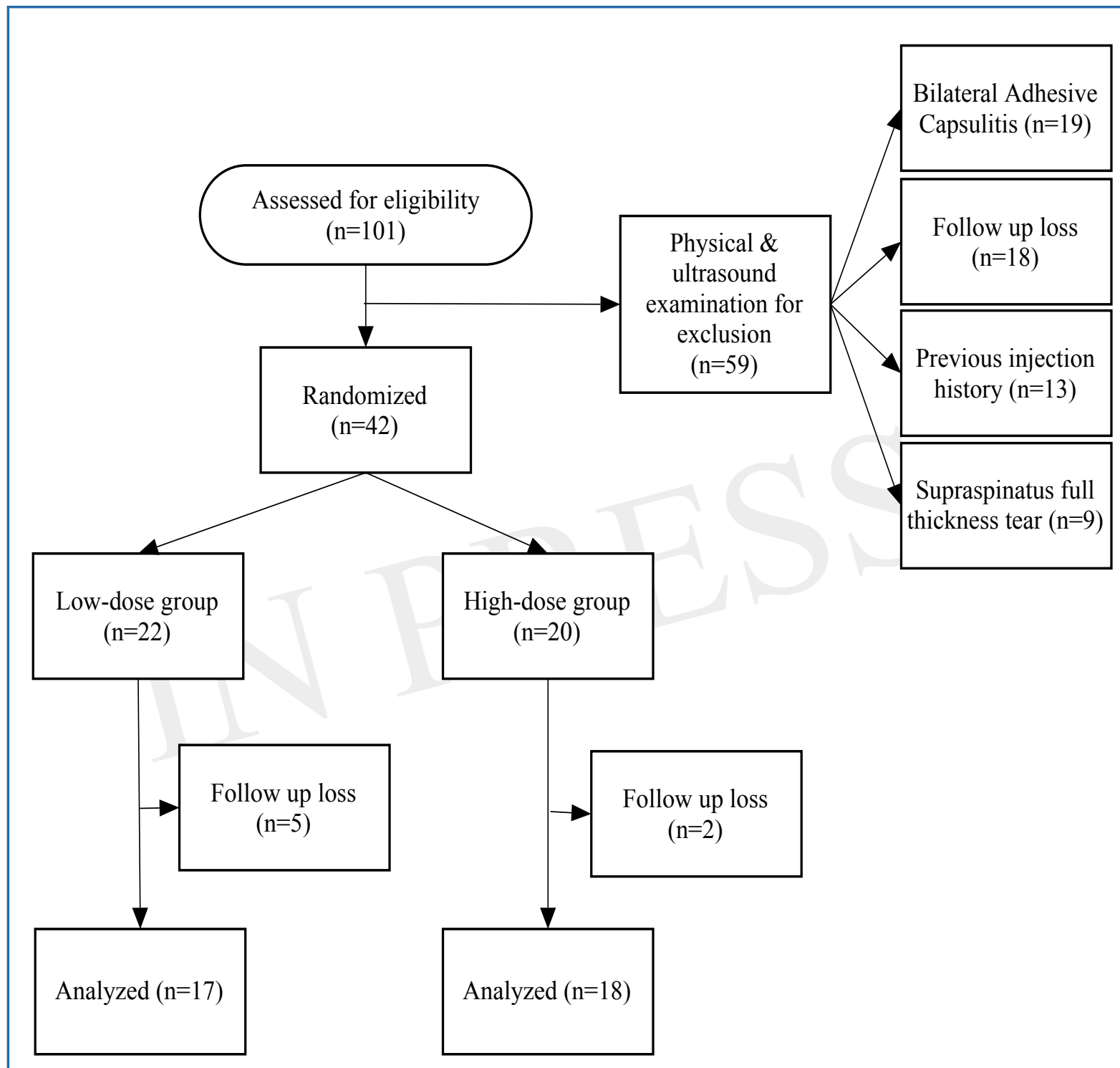

Fig. 1. Flow diagram showing the treatment process and assessment (Flowchart for study procedure).

and 1, 2, 3, and 4 weeks after injection. The physical examination and ultrasonography were performed by a single board-certified physiatrist (K.H.S). The follow-up outcome measures were measured by a single board-certified physiatrist (H.J.S) with 5 years of experience in musculoskeletal rehabilitation who was blind to group information.

\section{Statistical Analysis}

We compared the 2 groups in terms of age, gender, and affected side by performing a X2 analysis. A linear mixed model was used to assess overall group effects, and group-by-time interaction effects. The Mann-Whitney test was used to compare differences between groups. Significance was accepted for $P<$ 


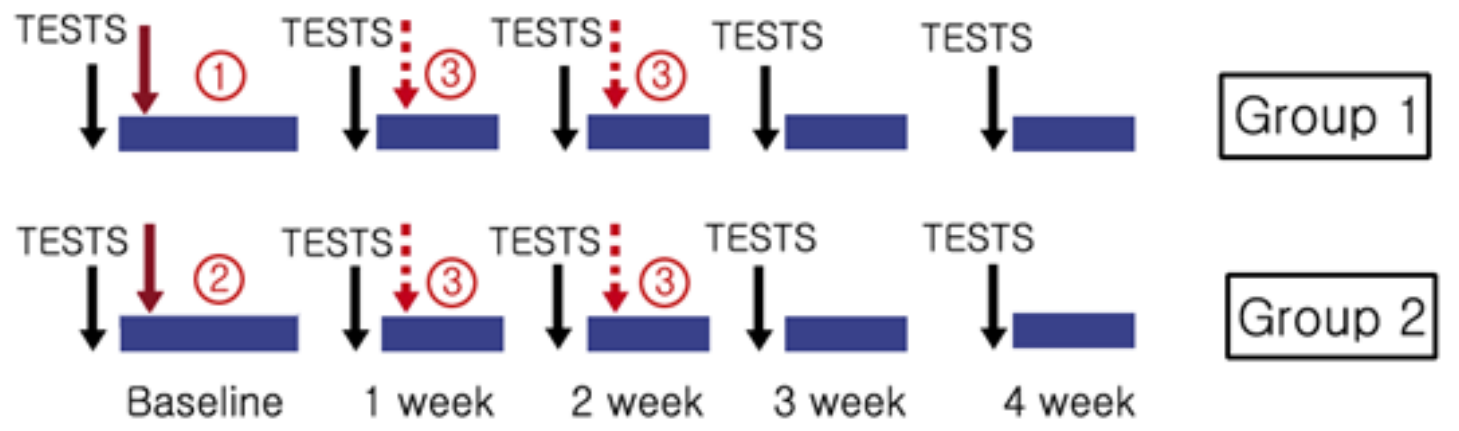

Fig. 2. Time-line diagram of the study design.

Group 1: $1 \mathrm{~mL}$ of $40 \mathrm{mg}$ of triamcinolone acetonide and $9 \mathrm{ml}$ of $1 \%$ lidocaine

Group 2: $0.5 \mathrm{~mL}$ of $40 \mathrm{mg}$ of triamcinolone acetonide and $9.5 \mathrm{~mL}$ of $1 \%$ lidocaine

(1): $1 \mathrm{~mL}$ of $40 \mathrm{mg}$ of steroid and $9 \mathrm{ml}$ of $1 \%$ lidocaine intra-articular injection

(2): $0.5 \mathrm{~mL}$ of $40 \mathrm{mg}$ of steroid and $9.5 \mathrm{ml}$ of $1 \%$ lidocaine intra-articular injection

(3): $10 \mathrm{~mL}$ of $1 \%$ lidocaine intra-articular injection

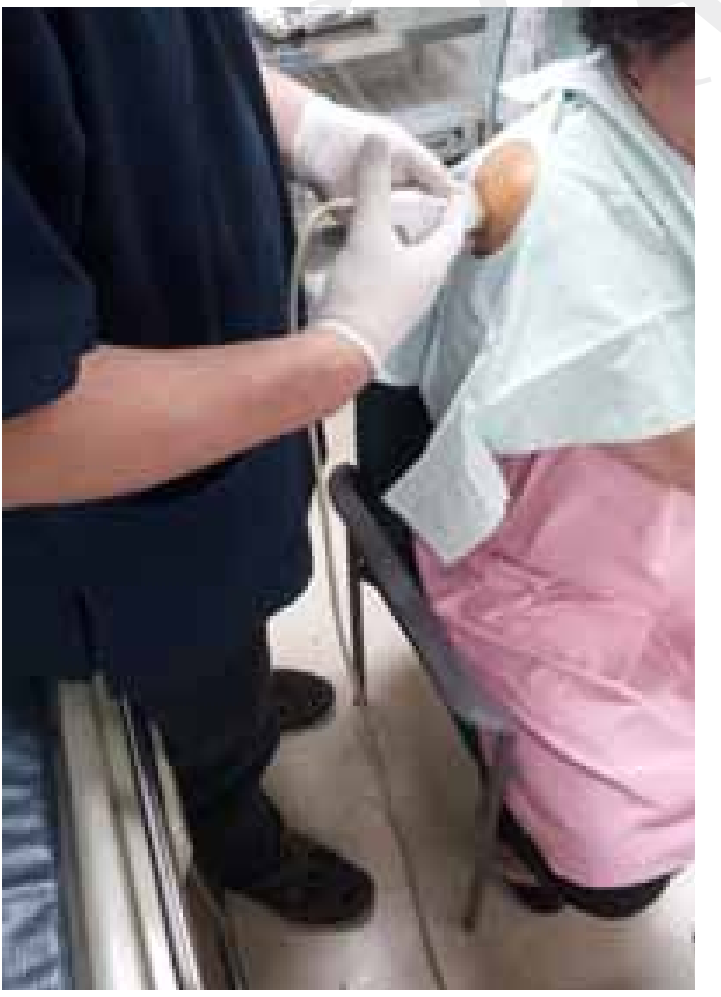

Fig. 3. Ultrasonography guided intra-articular injection at the posterior side of the shoulder.
0.05. Data were analyzed using SAS 9.2 software (SAS Institute, Cary, NC).

\section{RESULTS}

Table 1 shows the baseline characteristics of the patients. There were no significant differences between the 2 groups in age, gender, location, ROM, VAS, shoulder pain questionnaire, and ROM questionnaire. Table 2 shows the differences by time. Both groups' treatments were effective compared with their pretreated status in all measurements $(P<$ $0.05)$. However there were no statistical differences between groups between measurements, even when correcting for confounding factors and when comparing weekly differences to verify tendencies.

\section{DISCUSSION}

Understanding the etiology of the disease and treating according to the etiology is the principle of modern medical treatment, but there are many diseases that are not understood fully. Adhesive capsulitis is one of the diseases that fall into this category, though a part of the etiology is understood through biopsy or serum testing. For the earlier stages of adhesive capsulitis (stage 1 and 2), biopsies have revealed that there are inflammatory cells, and that there is an increase of inflammatory cytokines in the serum $(19,20)$. It is theorized that the pain in adhesive capsulitis is caused by inflammation, which is especially 


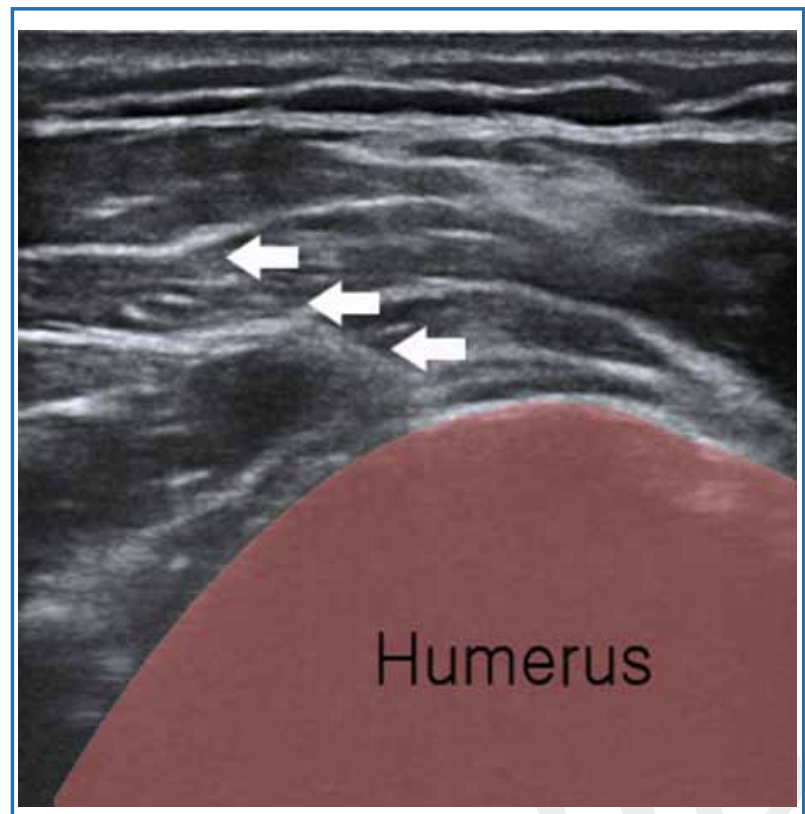

Fig. 4. Ultrasonography guided injection was performed with 23 gauge, $6 \mathrm{~cm}$ long needle at the posterior side of the shoulder in parallel to the transducer.

White arrow : needle

profound at the axillary fold of the joint capsule, the anterosuperior joint capsule, the coracohumeral ligament, and the rotator cuff interval (7). At stages 3 and 4 , inflammation subsides but fibrous tissues are found in biopsies. Adhesion and fibrosis of the synovial lining, and the thickening and the contraction of collagenous tissue around the glenohumeral joint capsule causes the joint capsule volume to decrease, limiting the range of motion of the shoulder. Thus, to treat adhesive capsulitis, a steroid injection was administered to patients with early stages of the disease to decrease inflammation, and hydrodilatation was performed to increase joint capsule volume. Both treatment modalities were found to be effective statistically $(10,12,21-26)$. However, Walmsley et al (27) found that, in a study that enrolled a total of 64 patients, many patients who were diagnosed as early stage might not have been categorized properly. Clinically, it is not possible to accurately determine the stage of the disease, as a patient may present with symptoms from different stages at the same

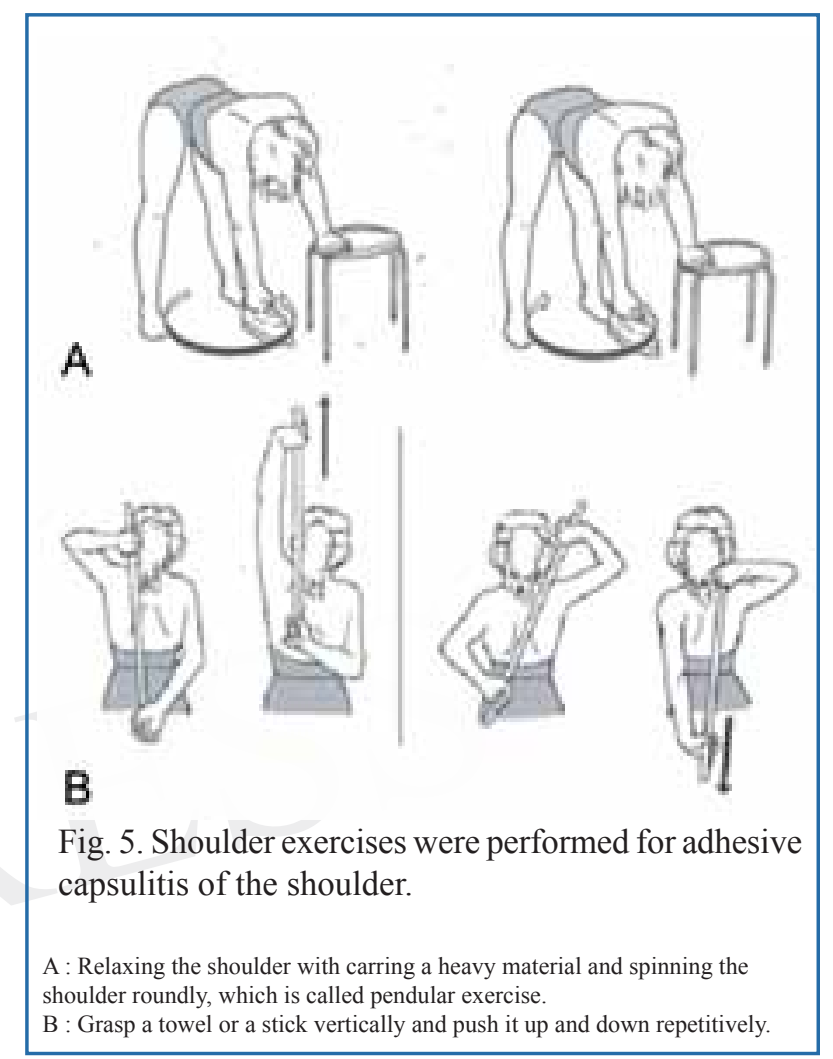

time (27). Even in our own study, we have found that patients show signs of both early and late stage adhesive capsulitis at the same time. For example, a patient can have both pain and limitation of motion of the shoulder, suggesting that both inflammation and fibrosis are occurring in the affected shoulder.

Even if there was a more effective way of differentiating between early and late stages, hydrodilatation at early stages can help the steroid reach a larger area due to increased joint space, and steroid injection at late stages can help subdue any residual inflammation. It is pathophysiologically sound to use both treatment methods in conjunction with each other, since they both help with overall efficacy.

Until now, most studies on adhesive capsulitis of the shoulder have been about the effects and optimal dose of steroid injection with hydrodilatation.

De jong et al (28) studied how the dosage of steroid affected the efficacy of treatment in patients who underwent only steroid injections. The patients were 
Table 1. Baseline characteristics of participants.

\begin{tabular}{|l|c|c|c|}
\hline & $\begin{array}{c}\mathbf{4 0} \mathbf{~ m g ~ s t e r o i d ~ i n j e c t i o n ~ g r o u p ~} \\
(\mathbf{n = 1 8})\end{array}$ & $\begin{array}{c}\mathbf{2 0 ~} \mathbf{~ m g ~ s t e r o i d ~ i n j e c t i o n ~ g r o u p ~} \\
(\mathbf{n = 1 7})\end{array}$ & $\boldsymbol{P}$ \\
\hline Sex (male:female) & $10: 8$ & $9: 8$ & 0.2578 \\
\hline Age (yr) & 57.83333 & 61.29412 & 0.8767 \\
\hline Side (right:left) & $11: 7$ & $8: 10$ & 0.4042 \\
\hline Flexion ROM & $162.8 \pm 17.0$ & $148.2 \pm 31.0$ & 0.1014 \\
\hline Abduction ROM & $137.8 \pm 30.6$ & $117.1 \pm 33.9$ & 0.0660 \\
\hline External rotation ROM & $71.5 \pm 16.7$ & $67.4 \pm 25.9$ & 0.5349 \\
\hline VAS & $6.2 \pm 5.1$ & $6.6 \pm 5.3$ & 0.5957 \\
\hline Shoulder pain questionnaire & $2.6 \pm 1.1$ & $2.2 \pm 1.1$ & 0.2441 \\
\hline Flexion posture & $4.8 \pm 0.7$ & $4.3 \pm 1.2$ & 0.1680 \\
\hline Abduction posture & $3.9 \pm 1.0$ & $3.5 \pm 1.1$ & 0.2559 \\
\hline Internal rotation posture & $3.3 \pm 1.1$ & $3.3 \pm 0.6$ & 0.9556 \\
\hline
\end{tabular}

ROM, Range Of Motion

VAS, Visual Analogue Scale

assigned to 2 groups: those who received $10 \mathrm{mg}$ triamcinolone and those who received $40 \mathrm{mg}$ triamcinolone. The 2 groups showed no differenence in ROM improvement, but it was concluded that $40 \mathrm{mg}$ triamcinolone was more effective at controlling pain and decreasing the rate of sleep disturbance (28).

Yoon et al (13) studied 53 patients with early stage adhesive capsulitis who underwent steroid injections consisting of a total volume of $5 \mathrm{~mL}$, and grouped the patients according to the amount of steroid they received: $40 \mathrm{mg}, 20 \mathrm{mg}$, and placebo. They found that there was no statistical difference in improvement between patient groups who underwent $20 \mathrm{mg}$ or 40 $\mathrm{mg}$, but that there was a difference between both groups and the placebo group. They recommended that $20 \mathrm{mg}$ of steroid should be administered (13). However, considering the fact that the volume of a normal shoulder joint capsule is $15-30 \mathrm{~mL}$, and the volume decreases by $5-6 \mathrm{~mL}$ when a patient is affected by adhesive capsulitis, (6) a $5 \mathrm{~mL}$ intraarticular injection might not have been sufficient to ensure that the $40 \mathrm{mg}$ of steroid was evenly distributed to all inflammation sites in the joint.

Tvetia et al (11) published a study comparing the efficacy of treatment between 2 patient groups: those who received only steroid injections and those who received steroid injections with hydrodilatation. They concluded that the 2 groups showed no difference in efficacy, although statistically not significant, the group that received steroid injections with hydrodilatation treatments showed a bigger improvement in shoulder pain and disability index compared to those who only received steroid injections (11).

Jacobs et al (29) studied 47 patients with adhesive capsulitis who were grouped and treated by hydrodilatation only, steroid injection only, or steroid injection with hydrodilatation. There were statistically sound improvements in abduction and flexion ROM in all groups. The steroid injection with hydrodilatation group was the most improved, however, there were no statistical differences with the steroid injection only group (29).

Results varied between studies even though almost the same protocol studies were conducted. It could be because of the difference in skill, improvements in ultrasound machines, and the variety of patients. However, most of the studies showed that there were improvements when treating with a steroid injection or hydrodilatation.

Thus, we concluded that steroid injection combined with hydrodilatation is the optimal treatment combination, as long as there are no adverse effects, and conducted this study to see how different dosages of steroid affects the efficacy of the treatment. 
Table 2. Changes of Outcome Measurements after Intra-articular Injections

\begin{tabular}{|c|c|c|c|c|c|}
\hline & $\begin{array}{c}\text { High dose }(40 \mathrm{mg}) \\
\text { group } \\
(\text { mean } \pm \mathrm{SD})\end{array}$ & $\begin{array}{c}P \text { value } \\
\text { (Week } 4- \\
\text { baseline) }\end{array}$ & $\begin{array}{c}\text { Low dose }(20 \mathrm{mg}) \\
\text { group } \\
(\text { mean } \pm \text { SD })\end{array}$ & $\begin{array}{c}P \text { value } \\
\text { (Week } 4 \text { - } \\
\text { baseline) }\end{array}$ & $\begin{array}{c}P \text { value } \\
\text { (Group by time } \\
\text { interaction) }\end{array}$ \\
\hline $\begin{array}{c}\text { Flexion ROM } \\
\text { Baseline } \\
\text { Week } 1 \\
\text { Week } 2 \\
\text { Week 3 } \\
\text { Week } 4 \\
\end{array}$ & $\begin{array}{c}162.8 \pm 17.1 \\
171.7 \pm 8.6 \\
173.9 \pm 7.8 \\
177.2 \pm 4.6 \\
179.4 \pm 2.4 \\
\end{array}$ & $<0.001$ & $\begin{array}{c}148.2 \pm 31.1 \\
154.7 \pm 32.8 \\
165.3 \pm 19.1 \\
172.4 \pm 11.5 \\
174.7 \pm 8.7 \\
\end{array}$ & $<0.001$ & 0.227 \\
\hline $\begin{array}{r}\text { Abduction ROM } \\
\text { Baseline } \\
\text { Week } 1 \\
\text { Week } 2 \\
\text { Week } 3 \\
\text { Week } 4\end{array}$ & $\begin{aligned} & 137.8 \pm 30.6 \\
& 159.4 \pm 22.1 \\
& 166.1 \pm 23.8 \\
& 176.1 \pm 9.8 \\
& 179.4 \pm 2.4 \\
&\end{aligned}$ & $<0.001$ & $\begin{array}{c}117.1 \pm 33.9 \\
142.4 \pm 31.5 \\
148.9 \pm 34.4 \\
160 \pm 24.7 \\
170 \pm 16.2\end{array}$ & $<0.001$ & 0.736 \\
\hline $\begin{array}{c}\text { External rotation ROM } \\
\text { Baseline } \\
\text { Week 1 } \\
\text { Week 2 } \\
\text { Week 3 } \\
\text { Week } 4\end{array}$ & $\begin{aligned} 71.9 & \pm 16.7 \\
78.1 & \pm 13.2 \\
82.2 & \pm 10.6 \\
86.7 & \pm 5.9 \\
89.4 & \pm 2.4\end{aligned}$ & $<0.001$ & $\begin{array}{l}67.4 \pm 25.9 \\
70.6 \pm 23.2 \\
73.6 \pm 22.6 \\
75.3 \pm 22.1 \\
82.4 \pm 14.4\end{array}$ & $<0.001$ & 0.687 \\
\hline $\begin{array}{r}\text { VAS } \\
\text { Baseline } \\
\text { Week 1 } \\
\text { Week 2 } \\
\text { Week 3 } \\
\text { Week } 4\end{array}$ & $\begin{array}{l}6.2 \pm 2.2 \\
3.2 \pm 2.2 \\
2.2 \pm 1.9 \\
1.3 \pm 1.3 \\
0.6 \pm 1.0\end{array}$ & $<0.001$ & $\begin{array}{c}6.6 \pm 2.4 \\
4 \pm 1.7 \\
2.9 \pm 1.7 \\
2.1 \pm 1.3 \\
1.4 \pm 1.7\end{array}$ & $<0.001$ & 0.977 \\
\hline $\begin{array}{c}\text { Shoulder pain questionnaire } \\
\text { Baseline } \\
\text { Week } 1 \\
\text { Week } 2 \\
\text { Week } 3 \\
\text { Week } 4 \\
\end{array}$ & $\begin{array}{l}2.6 \pm 1.1 \\
3.6 \pm 0.9 \\
3.6 \pm 1.1 \\
3.9 \pm 1.2 \\
4.6 \pm 0.8\end{array}$ & $<0.001$ & $\begin{array}{l}2.2 \pm 1.1 \\
2.7 \pm 1.1 \\
3.4 \pm 0.9 \\
3.9 \pm 0.9 \\
4.6 \pm 0.6\end{array}$ & $<0.001$ & 0.227 \\
\hline $\begin{array}{c}\text { Flexion posture } \\
\text { Baseline } \\
\text { Week } 1 \\
\text { Week } 2 \\
\text { Week } 3 \\
\text { Week } 4\end{array}$ & $\begin{array}{l}4.8 \pm 0.7 \\
4.6 \pm 1.0 \\
4.6 \pm 1.1 \\
4.8 \pm 0.7 \\
4.9 \pm 0.5\end{array}$ & $<0.001$ & $\begin{array}{l}4.3 \pm 1.2 \\
4.6 \pm 1.1 \\
4.8 \pm 0.5 \\
4.8 \pm 0.5 \\
4.9 \pm 0.2\end{array}$ & $<0.001$ & 0.182 \\
\hline $\begin{array}{r}\text { Abduction posture } \\
\text { Baseline } \\
\text { Week } 1 \\
\text { Week } 2 \\
\text { Week } 3 \\
\text { Week } 4 \\
\end{array}$ & $\begin{aligned} 3.9 & \pm 1.0 \\
4.2 & \pm 0.9 \\
4.6 & \pm 0.6 \\
4.7 & \pm 0.5 \\
5 & \pm 0\end{aligned}$ & $<0.001$ & $\begin{array}{l}3.5 \pm 1.1 \\
4.1 \pm 1.0 \\
4.4 \pm 0.8 \\
4.6 \pm 0.7 \\
4.9 \pm 0.3\end{array}$ & $<0.001$ & 0.841 \\
\hline $\begin{array}{c}\text { Internal rotation posture } \\
\text { Baseline } \\
\text { Week } 1 \\
\text { Week } 2 \\
\text { Week } 3 \\
\text { Week } 4\end{array}$ & $\begin{array}{l}3.3 \pm 1.1 \\
3.7 \pm 1.0 \\
3.9 \pm 1.0 \\
4.2 \pm 0.9 \\
4.6 \pm 0.6\end{array}$ & $<0.001$ & $\begin{array}{l}3.3 \pm 0.6 \\
3.6 \pm 0.8 \\
3.6 \pm 0.9 \\
3.9 \pm 1.2 \\
4.2 \pm 1.0\end{array}$ & $<0.001$ & 0.878 \\
\hline
\end{tabular}


Table 3. Changes of outcome measurements comparing with baseline after intra-articular injections.

\begin{tabular}{|c|c|c|c|}
\hline & $\begin{array}{l}\text { High dose (40 mg) group } \\
(\text { mean } \pm \text { SD) }\end{array}$ & $\begin{array}{l}\text { Low dose (20 mg) group } \\
(\text { mean } \pm \text { SD) }\end{array}$ & $\begin{array}{c}P \text { value } \\
\text { (Between-group comparison) }\end{array}$ \\
\hline $\begin{array}{r}\text { Flexion ROM } \\
\text { Baseline - Week } 1 \\
\text { Baseline - Week } 2 \\
\text { Baseline - Week } 3 \\
\text { Baseline - Week } 4\end{array}$ & $\begin{array}{c}-8.89 \pm 12.78 \\
-11.11 \pm 13.23 \\
-14.44 \pm 17.23 \\
-16.67 \pm 17.49\end{array}$ & $\begin{array}{c}-6.47 \pm 33.16 \\
-17.06 \pm 27.33 \\
-24.12 \pm 25.75 \\
-26.47 \pm 30.20\end{array}$ & $\begin{array}{l}0.660 \\
0.987 \\
0.287 \\
0.483\end{array}$ \\
\hline $\begin{array}{r}\text { Abduction ROM } \\
\text { Baseline - Week } 1 \\
\text { Baseline - Week } 2 \\
\text { Baseline - Week } 3 \\
\text { Baseline - Week } 4\end{array}$ & $\begin{array}{l}-21.67 \pm 28.13 \\
-28.33 \pm 31.30 \\
-38.33 \pm 30.53 \\
-41.67 \pm 30.34\end{array}$ & $\begin{array}{l}-25.29 \pm 27.87 \\
-31.76 \pm 34.68 \\
-42.94 \pm 30.77 \\
-52.94 \pm 30.98\end{array}$ & $\begin{array}{l}0.483 \\
0.782 \\
0.590 \\
0.287\end{array}$ \\
\hline $\begin{array}{r}\text { External rotation ROM } \\
\text { Baseline - Week } 1 \\
\text { Baseline - Week } 2 \\
\text { Baseline - Week } 3 \\
\text { Baseline - Week } 4\end{array}$ & $\begin{array}{c}-6.11 \pm 13.78 \\
-10.28 \pm 15.76 \\
-14.72 \pm 16.31 \\
-17.50 \pm 16.47\end{array}$ & $\begin{array}{l}-3.24 \pm 20.69 \\
-6.18 \pm 17.99 \\
-7.94 \pm 19.61 \\
-15.0 \pm 22.91\end{array}$ & $\begin{array}{l}0.732 \\
0.335 \\
0.195 \\
0.636\end{array}$ \\
\hline $\begin{array}{l}\text { VAS } \\
\text { Baseline - Week } 1 \\
\text { Baseline - Week } 2 \\
\text { Baseline - Week } 3 \\
\text { Baseline - Week } 4\end{array}$ & $\begin{array}{l}3.00 \pm 2.47 \\
4.00 \pm 2.63 \\
4.89 \pm 2.14 \\
5.56 \pm 2.15\end{array}$ & $\begin{array}{l}2.59 \pm 1.70 \\
3.65 \pm 2.42 \\
4.53 \pm 2.50 \\
5.18 \pm 3.11\end{array}$ & $\begin{array}{l}0.961 \\
0.987 \\
0.987 \\
0.832\end{array}$ \\
\hline $\begin{array}{c}\text { Shoulder pain questionnaire } \\
\text { Baseline - Week } 1 \\
\text { Baseline - Week } 2 \\
\text { Baseline - Week } 3 \\
\text { Baseline - Week } 4\end{array}$ & $\begin{array}{l}-0.94 \pm 1.11 \\
-1.00 \pm 1.68 \\
-1.33 \pm 1.85 \\
-2.00 \pm 1.41\end{array}$ & $\begin{array}{l}-0.53 \pm 1.01 \\
-1.24 \pm 1.44 \\
-1.76 \pm 1.56 \\
-2.41 \pm 1.23\end{array}$ & $\begin{array}{l}0.443 \\
0.684 \\
0.590 \\
0.443\end{array}$ \\
\hline $\begin{array}{l}\text { Flexion posture } \\
\text { Baseline - Week } 1 \\
\text { Baseline - Week } 2 \\
\text { Baseline - Week } 3 \\
\text { Baseline - Week } 4\end{array}$ & $\begin{array}{c}0.17 \pm 1.29 \\
0.22 \pm 1.00 \\
-0.06 \pm 1.06 \\
-0.11 \pm 0.90\end{array}$ & $\begin{array}{l}-0.35 \pm 0.61 \\
-0.53 \pm 1.01 \\
-0.53 \pm 1.01 \\
-0.65 \pm 1.06\end{array}$ & $\begin{array}{l}0.134 \\
0.103 \\
0.273 \\
0.173\end{array}$ \\
\hline $\begin{array}{r}\text { Abduction posture } \\
\text { Baseline - Week } 1 \\
\text { Baseline - Week } 2 \\
\text { Baseline - Week } 3 \\
\text { Baseline - Week } 4\end{array}$ & $\begin{array}{l}-0.28 \pm 0.46 \\
-0.44 \pm 1.58 \\
-0.78 \pm 1.11 \\
-1.06 \pm 1.00\end{array}$ & $\begin{array}{l}-0.53 \pm 0.94 \\
-0.88 \pm 1.50 \\
-1.12 \pm 1.36 \\
-1.35 \pm 1.11\end{array}$ & $\begin{array}{l}0.546 \\
0.483 \\
0.318 \\
0.463\end{array}$ \\
\hline $\begin{array}{r}\text { Internal rotation posture } \\
\text { Baseline - Week1 } \\
\text { Baseline - Week2 } \\
\text { Baseline - Week3 } \\
\text { Baseline - Week4 }\end{array}$ & $\begin{array}{l}-0.44 \pm 0.86 \\
-0.61 \pm 1.54 \\
-0.89 \pm 1.41 \\
-1.28 \pm 1.18\end{array}$ & $\begin{array}{l}-0.35 \pm 0.70 \\
-0.35 \pm 1.17 \\
-0.59 \pm 1.37 \\
-0.94 \pm 1.09\end{array}$ & $\begin{array}{l}0.858 \\
0.782 \\
0.684 \\
0.568\end{array}$ \\
\hline
\end{tabular}

The main adverse effect of hydrodilatation treatment is that the patients suffer from pain due to the large volume of hydrodilatation. In this study, we performed hydrodilatation by weekly serial injection of $10 \mathrm{~mL}$ lidocaine to reduce the pain; as a result, no patients reported pain.

One weak point of our study is the absence of a control group: a group that was administered hydrodilatation without steroid injection. However, this study was originally set up as a double-blinded randomized controlled study. Triamcinolone acetate has a unique milky color. So if we set up the control group with transparent normal saline or mixed local anesthetic fluid, it would have been very easy to dif- 
ferentiate the control group. So we could not create a control group by this research methodology. Another weak point is that the follow-up period was not long enough to judge the long-term effect of the treatment. Our study was conducted for 4 weeks, which is only suitable for analyzing the short-term effect. The third weak point is that previous studies used various total doses of water for hydrodilatation $(10 \mathrm{~mL}-40 \mathrm{~mL}$ water), whereas in our study we selected $10 \mathrm{~mL}$ and it is unclear whether this volume is sufficient to cause an effective distension of the joint capsule. Although we tried to confirm the flow of injection through Doppler ultrasound when carrying out the intraarticular injections, we could not fully check whether all the injection fluid was able to spread into the joint space without leakage. This can be considered a limitation. Finally, the study about dosing over $40 \mathrm{mg}$ has not yet been

\section{REFERENCES}

1. Binder Al, Bulgen DY, Hazleman BL, Roberts S. Frozen shoulder: A long-term prospective study. Ann Rheum Dis 1984; 43:361-364.

2. Lloyd-Roberts GC, French PR. Periarthritis of the shoulder: A study of the disease and its treatment. Br Med J 1959; 1:15691571.

3. Codman EA. The shoulder: Rupture of the supraspinatus tendon and other lesions in or about the subacromial bursa. T. Todd Company, Boston, 1934.

4. Neviaser JS. Adhesive capsulitis of the shoulder. J Bone Joint Surg 1945; 27:211-222.

5. Robinson $\mathrm{C}$, Seah KM, Chee $\mathrm{Y}$, Hindle $\mathrm{P}$, Murray I. Frozen shoulder. J Bone Joint Surg Br 2012; 94:1-9.

6. Lundberg BJ. The frozen shoulder: Clinical and radiographical observations the effect of manipulation under general anesthesia structure and glycosaminoglycan content of the joint capsule local bone metabolism. Acta Orthopaedica 1969; 40:1-59.

7. Lewis J. Frozen shoulder contracture syndrome - Aetiology, diagnosis and management. Man Ther 2015; 20:2-9.

8. Hannafin J, DiCarlo E, Wickiewicz T, Warren R. Adhesive capsulitis: Capsular fibroplasia of the glenohumeral joint. J Shoulder Elbow Surg 1994; 3:435.

9. Neviaser AS, Hannafin JA. Adhesive capsulitis: A review of current treatment. Am J Sports Med 2010; 38:2346-2356.

10. Watson L, Bialocerkowski A, Dalziel R, Balster S, Burke F, Finch C. Hydrodilatation (distension arthrography): A long-term clinical outcome series. Br J Sports Med 2007; 41:167-173.

11. Tveita EK, Tariq R, Sesseng S, Juel NG, Bautz-Holter E. Hydrodilatation, corticosteroids and adhesive capsulitis: A randomized controlled trial. BMC Musculoskelet Disord 2008; 9:53.

12. Trehan RK, Patel S, Hill AM, Curtis MJ, Connell DA. Is it worthwhile to offer repeat hydrodilatation for frozen shoulder after 6 weeks? Int J Clin Pract 2010; 64:356-359. done. Therefore, a successive study is necessary to find the optimal steroid dosage.

However, our study was a double-blinded randomized controlled study, and was based on an analysis of the most current pathophysiology and treatment methods of adhesive capsulitis. The study also provided an optimal treatment modality for adhesive capsulitis.

In conclusion, steroid injection with hydrodilatation could be an optimal treatment for patients with adhesive capsulitis. Steroid doses of $20 \mathrm{mg}$ or $40 \mathrm{mg}$ alone are not related with an improvement of the disease.

\section{ACKNOWLEDGEMENT}

We thank the registered nurse (K.I.S) outpatient department for grouping the patients.

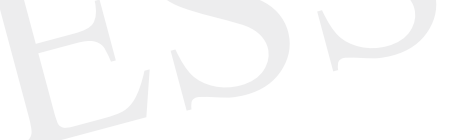

13. Yoon SH, Lee HY, Lee HJ, Kwack KS. Optimal dose of intraarticular corticosteroids for adhesive capsulitis: A randomized, triple-blind, placebo-controlled trial. Am J Sports Med 2013; 41:1133-1139.

14. Maund E, Craig D, Suekarran S, Neilson A, Wright K, Brealey S, Dennis L, Goodchild L, Hanchard N, Rangan A, Richardson G, Robertson J, McDaid C. Management of frozen shoulder: A systematic review and cost-effectiveness analysis. Health Technol Assess 2012; 16:1-264.

15. Lee HJ, Lim KB, Kim DY, Lee KT. Randomized controlled trial for efficacy of intra-articular injection for adhesive capsulitis: Ultrasonography-guided versus blind technique. Arch Phys Med Rehabil 2009; 90:1997-2002.

16. Hong JY, Yoon SH, Moon do J, Kwack KS, Joen B, Lee HY. Comparison of high- and low-dose corticosteroid in subacromial injection for periarticular shoulder disorder: A randomized, triple-blind, placebo-controlled trial. Arch Phys Med Rehabil 2011; 92:1951-1960.

17. Vermeulen HM, Rozing PM, Obermann WR, le Cessie S, Vliet Vlieland TP. Comparison of high-grade and low-grade mobilization techniques in the management of adhesive capsulitis of the shoulder: Randomized controlled trial. Phys Ther 2006; 86:355368.

18. Fayad F, Lefevre-Colau M-M, Gautheron V, Macé $Y$, Fermanian J, Mayoux-Benhamou A, Roren A, Rannou F, Roby-Brami A, Revel M, Poiraudeau S. Reliability, validity and responsiveness of the French version of the questionnaire Quick Disability of the Arm, Shoulder and Hand in shoulder disorders. Manual Therapy 2009; 14:206-212.

19. Franceschi F, Longo UG, Ruzzini L, Morini S, Battistoni F, Dicuonzo G, Maffulli N, Denaro V. Circulating substance P levels and shoulder joint contracture after arthroscopic repair of the rotator cuff. Br J Sports Med 2008; 42:742-745.

20. Andersson G, Backman LJ, Scott A, Lorentzon R, Forsgren S, 
Danielson P. Substance P accelerates hypercellularity and angiogenesis in tendon tissue and enhances paratendinitis in response to Achilles tendon overuse in a tendinopathy model. $\mathrm{Br}$ J Sports Med 2011; 45:1017-1022.

21. der van Windt D, Koes B, Deville W, Boeke A, De Jong B, Bouter L. Effectiveness of corticosteroid injections versus physiotherapy for treatment of painful stiff shoulder in primary care: Randomised trial. BMJ 1998; 317:1292-1296.

22. Bulgen D, Binder A, Hazleman B, Dutton J, Roberts S. Frozen shoulder: Prospective clinical study with an evaluation of three treatment regimens. Ann Rheum Dis 1984; 43:353-360.

23. Rizk T, Pinals R, Talaiver A. Corticosteroid injections in adhesive capsulitis: Investigation of their value and site. Arch Phys Med Rehabil 1991; 72:20-22.

24. Quraishi N, Johnston P, Bayer J, Crowe M, Chakrabarti A. Thawing the frozen shoulder: A randomised trial comparing manipulation under anaesthesia with hydrodilatation. $J$ Bone Joint Surg Br 2007; 89:1197-1200.
25. Gam A, Schydlowsky P, Rossel I, Remvig L, Jensen E. Treatment of frozen shoulder with distension and glucorticoid compared with glucorticoid alone: A randomised controlled trial. Scand J Rheumatol 1998; 27:425-430.

26. Khan A, Mowla A, Shakoor M, Rahman M. Arthrographic distension of the shoulder joint in the management of frozen shoulder. Mymensingh Med J: MMJ 2005; 14:67-70.

27. Walmsley S, Osmotherly PG, Rivett DA. Clinical identifiers for early-stage primary/idiopathic adhesive capsulitis: Are we seeing the real picture? Phys Ther 2014; 94:968-976.

28. de Jong BA, Dahmen R, Hogeweg JA, Marti RK. Intra-articular triamcinolone acetonide injection in patients with capsulitis of the shoulder: A comparative study of two dose regimens. Clin Rehabil 1998; 12:211-215.

29. Jacobs LG, Barton MA, Wallace WA, Ferrousis J, Dunn NA, Bossingham DH. Intra-articular distension and steroids in the management of capsulitis of the shoulder. BMJ 1991; 302:14981501.

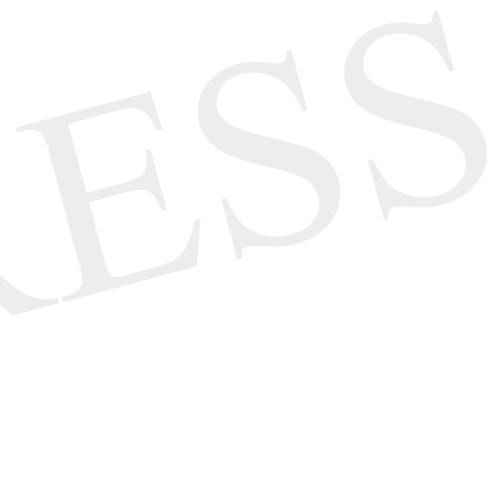

